\title{
Electrically bioactive coating on Ti with bi-layered SnO2-TiO2 hetero-structure for improving osteointegration
}

DOI:

10.1039/C8TB00709H

\section{Document Version}

Accepted author manuscript

Link to publication record in Manchester Research Explorer

Citation for published version (APA):

Zhou, R., Han, Y., Cao, J., Li, M., Jin, G., Luo, H., Zhang, L., \& Su, B. (2018). Electrically bioactive coating on Ti with bi-layered $\mathrm{SnO}_{2}-\mathrm{TiO}_{2}$ hetero-structure for improving osteointegration. Journal of Materials Chemistry $\mathrm{B}$, 6(23), 3989-3998. https://foi.org/10.1039/C8TB00709H

\section{Published in:}

Journal of Materials Chemistry B

\section{Citing this paper}

Please note that where the full-text provided on Manchester Research Explorer is the Author Accepted Manuscript or Proof version this may differ from the final Published version. If citing, it is advised that you check and use the publisher's definitive version.

\section{General rights}

Copyright and moral rights for the publications made accessible in the Research Explorer are retained by the authors and/or other copyright owners and it is a condition of accessing publications that users recognise and abide by the legal requirements associated with these rights.

\section{Takedown policy}

If you believe that this document breaches copyright please refer to the University of Manchester's Takedown Procedures [http://man.ac.uk/04Y6Bo] or contact uml.scholarlycommunications@manchester.ac.uk providing relevant details, so we can investigate your claim.

\section{OPEN ACCESS}




\section{Journal of \\ Materials Chemistry B}

\section{Accepted Manuscript}

This article can be cited before page numbers have been issued, to do this please use: R. Zhou, Y. Han, J.

Cao, M. Li, G. Jin, H. Luo, L. Zhang and B. Su, J. Mater. Chem. B, 2018, DOI: 10.1039/C8TB00709H.

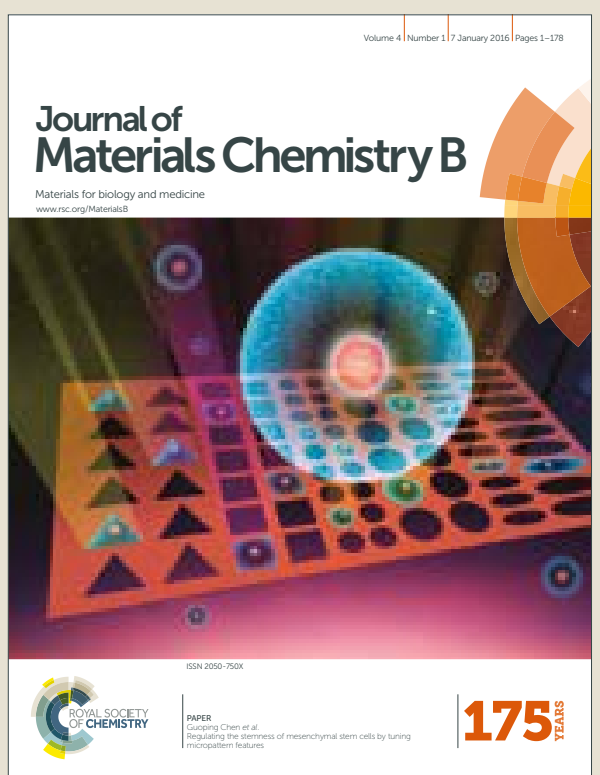

This is an Accepted Manuscript, which has been through the Royal Society of Chemistry peer review process and has been accepted for publication.

Accepted Manuscripts are published online shortly after acceptance, before technical editing, formatting and proof reading. Using this free service, authors can make their results available to the community, in citable form, before we publish the edited article. We will replace this Accepted Manuscript with the edited and formatted Advance Article as soon as it is available.

You can find more information about Accepted Manuscripts in the author guidelines.

Please note that technical editing may introduce minor changes to the text and/or graphics, which may alter content. The journal's standard Terms \& Conditions and the ethical guidelines, outlined in our author and reviewer resource centre, still apply. In no event shall the Royal Society of Chemistry be held responsible for any errors or omissions in this Accepted Manuscript or any consequences arising from the use of any information it contains. 
Received 00th January 20xx, Accepted 00th January 20xx DOI: 10.1039/x0xx00000x

www.rsc.org/

\title{
Electrically bioactive coating on $\mathrm{Ti}$ with bi-layered $\mathrm{SnO}_{2}-\mathrm{TiO}_{2}$ hetero-structure for improving osteointegration
}

\author{
Rui Zhou, ${ }^{\text {a,e }}$ Yong Han, ${ }^{* a}$ Jianyun Cao, ${ }^{\mathrm{b}}$ Ming Li, ${ }^{\mathrm{c}}$ Guorui Jin, ${ }^{\mathrm{d}}$ Haoteng Luo, ${ }^{\mathrm{a}}$ Lizhai Zhang ${ }^{\mathrm{a}}$ and Bo Su \\ $* \mathrm{e}$

\begin{abstract}
The potential for the use of electric stimulation to control cell behavior on a surface has been well documented. In terms of orthopedic applications, there is a need to develop bioactive surfaces with a built-in electric field for clinically relevant materials, such as the load-bearing titanium (Ti). In this work, a bi-layered $\mathrm{SnO}_{2}-\mathrm{TiO}_{2}$ coating is fabricated using microarc oxidation and subsequent hydrothermal treatment to adjust the surface electrical properties for improving bioactivity. The oxidized titanium interlayer on $\mathrm{Ti}$ substrate allows the growth of $\mathrm{SnO}_{2}$ nanorods with different morphologies which leads to a built-in $n-n$ heterojunction of $\mathrm{SnO}_{2}$ and $\mathrm{TiO}_{2}$ on $\mathrm{Ti}$ surface with varied surface electrical properties. The crystallization of the $\mathrm{TiO}_{2}$ interlayer facilitates the growth of $\mathrm{SnO}_{2}$ nanorods, showing excellent hydrophilicity and good apatite-inducing ability due to the formation of heterojunction. The results suggest that the bi-layered $\mathrm{SnO}_{2}-\mathrm{TiO}_{2}$ coating with electrically stimulated bioactivity could provide a novel way to enhance osteointegration on Ti surface.
\end{abstract}

\section{Introduction}

Electric stimulation offered by externally applied electric fields plays an important role in wound healing and tissue regeneration which can direct cell behavior in a predictable manner. ${ }^{1,2}$ An increasing number of studies from recent years have shown that certain electric stimulation can promote in vitro osteoblast differentiation and apatite deposition via the change of surface wettability. ${ }^{3,4}$ Though some materials have shown the capability to mediate the electric stimulus, such as conductive polymers, piezoelectric and carbon-based materials, 5 the electric stimulus offered by additional equipment is still inconvenient to conduct on an implant for orthopedic applications. Learning how to use such electric stimulation with a built-in electric field and applying them to clinically relevant materials could allow for the development of a new generation of implant surface which can be optimized for bone repair. 5

$\mathrm{Ti}$ and its alloys are some of the most important biomaterials that are commonly used for bone bonding implant application. ${ }^{6,7}$ Electric stimulus on Ti surface could be used to control the biological response and improve bone

\footnotetext{
a. State Key Laboratory for Mechanical Behavior of Materials, Xi'an Jiaotong University, Xi'an 710049, P.R. China.*E-mail: yonghan@xjtu.edu.cn

b. School of Materials, University of Manchester, Manchester M13 9PL, UK.

c. Honghui Hospital, Xi'an Jiaotong University College of Medicine, Xi' an 710054, P.R. China.

d. Bioinspired Engineering and Biomechanics Center, Xi'an Jiaotong University, Xi'an 710049, P.R. China.

e. Bristol Dental School, University of Bristol, Bristol BS1 2LY, UK. *E-mail: b.su@bristol.ac.uk

Electronic Supplementary Information (ESI) available. See DOI: $10.1039 / x 0 x \times 00000 x$
}

bonding at implant surfaces. 8 In the development of electrically bioactive implant, there is thus a great need for surface designation which can produce a well-defined built-in electric field to mediate transformation of electron carriers with expected surface charge enrichment, ${ }^{9}$ similar to the electric stimulus provided by externally applied electric fields to control the wettability of implant surface. ${ }^{3}$

A promising method for creation of such built-in electric field is the use of heterojunction, which has recently received massive interest for the fabrication of solar cell to promote charge transfer. ${ }^{9-11}$ Since the intriguing electron transfer ability of heterojunction with type II band alignment structure can efficiently enhance the separation of electronic carriers, ${ }^{12}$ the electron carriers and oxygen vacancies will show the obvious difference in distribution at the heterojunction which can be mediated by the structure of semiconductor layer. 13,14 Fortunately, this phenomenon reveals that a bi-layered heterojunction with a suitable feature on $\mathrm{Ti}$ will benefit bioactivity by adjusting surface wettability and receptor response because the oxygen vacancies can react with $\mathrm{H}_{2} \mathrm{O}$ to form -OH groups. ${ }^{15}$ Meanwhile, the bone tissue is accepted as a piezoelectric material, which can continuously provide the electrical signal during movement, ${ }^{16}$ leading to an unbalanced state of the built-in electrical field based on heterojunction. Thus, the long-term availability of the electrically stimulated bioactivity from the heterojunction coating could be ensured, because electron carriers will continuously simulate the surrounding bone tissue based on the response to the unbalanced built-in electrical field.

The hybridization of $\mathrm{SnO}_{2}$ with $\mathrm{TiO}_{2}$ as a heterojunction is one of the most appealing solutions to render $\mathrm{Ti}$ implant surface with electrical bioactivity, as the band gap of $\mathrm{SnO}_{2}$ and 
$\mathrm{TiO}_{2}$ heterojunction belongs to the type II band alignment structure. ${ }^{17}$ Therefore, the electrons will transfer from $\mathrm{TiO}_{2}$ to $\mathrm{SnO}_{2}$, benefiting the enrichment of electron carriers on $\mathrm{SnO}_{2}$, which would be used as the electric stimulation to regulate host tissue response. So far, the bonding between coating and substrate is still a key factor to ensure the success of the application. Fortunately, the coating fabricated by microarc oxidation (MAO) shows excellent bonding with Ti substrate. Meanwhile, both the structure and phase of the $\mathrm{TiO}_{2}$ based coating can be adjusted by changing processing parameters. 18,19 The effect of $\mathrm{TiO}_{2}$ crystallinity for the as-designed $\mathrm{SnO}_{2}-$ $\mathrm{TiO}_{2}$ coating on bioactivity can be investigated. Furthermore, various structures of the nano-sized $\mathrm{SnO}_{2}$ crystal can be fabricated through hydrothermal treatment, ${ }^{20}$ resulting in a bilayered $\mathrm{SnO}_{2}-\mathrm{TiO}_{2}$ coating formed on $\mathrm{Ti}$. Because $\mathrm{SnO}_{2}$ is normally considered as a biocompatible material without bioactivity, even after simulated body fluid (SBF) immersion, 21,22 bi-layered $\mathrm{SnO}_{2}-\mathrm{TiO}_{2}$ coating would offer a good platform for the investigation of surface electrical properties on osteointegration of Ti implant.

\section{Experimental section}

\section{Coating preparation}

The pure Ti plates $\left(10 \times 10 \times 1 \mathrm{~mm}^{3}\right)$ and rods $\left(\Phi 2 \times \mathrm{L} 6 \mathrm{~mm}^{3}\right)$ (Grade II, Baoji Haibao special metal materials Co., China) were ground with 600\# and $1000 \#$ abrasive papers to wipe off the oxidized layer, and then ultrasonically washed with acetone and distilled water. The Ti plates were used as substrate for surface modification and coating characterization, while the $\mathrm{Ti}$ rods were used as the Ti implants for the surface modification and animal surgery. Titanium oxide coating was prepared on $\mathrm{Ti}$ substrate via microarc oxidation (MAO) in an electrolyte containing EDTA-2Na (15 g. $\left.\mathrm{L}^{-1}\right)$ and $\mathrm{NaOH}\left(7 \mathrm{~g} \cdot \mathrm{L}^{-1}\right)$. MAO-Non, MAO-Anatase, and $\mathrm{MAO}-\mathrm{TiO}_{2}$ were labeled as the MAO treated $\mathrm{Ti}$ substrates corresponding to the coating phase formed at different applied voltages of 250, 350 and $450 \mathrm{~V}$, respectively. The samples were hanged in the cup and the side towards the bottom of the cup to ensure that the $\mathrm{SnO}_{2}$ grows without depositions on its surface during the hydrothermal treatment in the solution containing $0.5 \mathrm{~g} \mathrm{SnCl}_{4} \cdot 5 \mathrm{H}_{2} \mathrm{O}, 0.7 \mathrm{~g}$ $\mathrm{NaOH}, 30 \mathrm{~mL}$ water and $10 \mathrm{~mL}$ ethanol, at $200{ }^{\circ} \mathrm{C}$ for $24 \mathrm{~h}$. HT$\mathrm{Ti}, \mathrm{SnO}_{2}-\mathrm{Non}, \mathrm{SnO}_{2}$-Anatase, and $\mathrm{SnO}_{2}-\mathrm{TiO}_{2}$ were used to represent the $\mathrm{Ti}$ and MAO coated samples after hydrothermal treatment (Table S1, ESI + ).

\section{Characterization}

$X$-ray diffraction (XRD). The phase composition of the plate samples was analyzed by X-ray diffraction (XRD, D/max-gB, Japan).

Scanning electron microscopy (SEM) and energy-dispersive X-ray spectrometer (EDS). Scanning electron microscopy (SEM, Helios Nanolab 600i, FEI Co., USA) was used to observe the surface and facture morphology. Meanwhile, the surface elemental concentrations of the samples were detected by an energy dispersive X-ray spectrometer (EDAX, USA) equipped on the SEM system. DOI: 10.1039/C8TB00709H

Transmission electron microscopy (TEM). A transmission electron microscopy (TEM, Tecnai G2F30, FEl Co., USA) instrument with an accelerated voltage of $300 \mathrm{kV}$ was used to analyze the microstructure of the $\mathrm{SnO}_{2}-\mathrm{TiO}_{2}$. Bright and dark field images were used to analyze the morphology of the nanorod. The elemental compositions were analyzed by EDS equipped on the TEM system. The high resolution TEM (HRTEM) pattern was analyzed using the Fast Fourier Transform (FFT) technique to identify the phase of the nanorods. A selected area electron diffraction (SAED) pattern was acquired to analyze the phase of the nanorod.

Contact angle. The contact angles of deionized water on the surfaces were measured using the liquid drop method on a contact angle goniometer (CA, CAM101, KSV Instruments Ltd., Finland).

Zeta-potential. Zeta-potential of the sample surface was determined by a streaming current electro kinetic analyzer (SurPass, Anton Paae GmbH, Graz, Austria). The zeta-potential value was calculated based on Fairbrother-Mastin approach, and $1 \mathrm{mM} \mathrm{KCl}$ was used as background electrolyte solution.

Surface roughness. The sample surface was scanned by confocal laser scanning microscope (CLSM, Olympus3000, Japan) over an area of $256 \times 256 \mu \mathrm{m}^{2}$ to calculate the value of surface area roughness ( $R a)$ and peak-to-valley height ( $R z)$.

Fourier transform infrared (FT-IR) spectroscopy. Fourier transform infrared spectroscopy (Magna-IR 560 E.S.P., Nicolet Corp., USA) was used to analyze the deposition formed on the $\mathrm{SnO}_{2}-\mathrm{TiO}_{2}$ surface after SBF immersion.

X-ray photoelectron spectroscopy (XPS). An X-ray photoelectron spectroscopy (K-Alpha, Thermofisher Scienticfic Co., USA) was used to detect the chemical compositions of the $\mathrm{SnO}_{2}-\mathrm{TiO}_{2}$ surface. In the XPS experiment, an AIK $\alpha$ (1486.6 eV) $X$-ray source was used for the XPS work under a vacuum of $1.0 \times 10^{-8} \mathrm{mbar}$. The current of $X$-ray beam was $6 \mathrm{~mA}$ and the resolution for energy was $0.5 \mathrm{eV}$ with a scanning step of 0.1 $\mathrm{eV}$. The regions of $400 \mu \mathrm{m}^{2}$ on the sample surfaces were analyzed. The measured binding energies were calibrated by the $\mathrm{C} 1 \mathrm{~s}$ (hydrocarbon $\mathrm{C}-\mathrm{C}, \mathrm{C}-\mathrm{H}$ ) of $284.6 \mathrm{eV}$. And the chemical states of C, O, Ti and Sn were analyzed.

Electrochemical analysis. The Mott-Schottky plots of the samples were measured on an electrochemical workstation (CHI760E, Shanghai). The voltage was scanned from $-0.5 \mathrm{~V}$ to $0.5 \mathrm{~V}$ versus SCE (saturated calomel reference electrode) at a frequency of $10,000 \mathrm{~Hz}$ and $0.5 \mathrm{M} \mathrm{Na}_{2} \mathrm{SO}_{4}$ was used as the electrolyte. The carrier density of the electrode can be calculated from the intercept and the slope of Mott-Schottky plots using Equation (1).

$\mathrm{C}^{-2}=2\left(\mathrm{E}-\mathrm{E}_{\mathrm{fb}}-k \mathrm{~T} / \mathrm{e}\right) /\left(\mathrm{N}_{\left.\mathrm{D} \varepsilon \varepsilon_{0} \mathrm{e} \mathrm{A}^{2}\right)}\right.$

Where $N_{D}$ is the carrier density, $C$ is the space charge capacitance, $E_{\mathrm{fb}}$ is flat band potential, $A$ is the active surface, $\varepsilon$ is the dielectric constant of surface layer, $\varepsilon_{0}$ is vacuum 
permittivity, $k$ is the Boltzmann constant, $\mathrm{T}$ is the absolute temperature and $\mathrm{e}$ is the elementary charge.

Simulated body fluid (SBF) treatment. SBF treatment was used to evaluate the apatite-inducing ability of the samples. ${ }^{22}$ The SBF was prepared by dissolving $\mathrm{NaCl}, \mathrm{NaHCO}_{3}, \mathrm{KCl}, \mathrm{K}_{2} \mathrm{HPO}_{4} \cdot 3 \mathrm{H}_{2} \mathrm{O}$, $\mathrm{MgCl}_{2} \cdot 6 \mathrm{H}_{2} \mathrm{O}, \mathrm{CaCl}_{2}$, and $\mathrm{Na}_{2} \mathrm{SO}_{4}$ in deionized water. Then, it was buffered at $\mathrm{pH} \quad 7.40$ with trishydroxymethylaminomethane $\left(\left(\mathrm{CH}_{2} \mathrm{OH}\right)_{3} \mathrm{CNH}_{2}\right)$ and $1.0 \mathrm{~mol} \mathrm{~L}^{-1}$ $\mathrm{HCl}$ at $37{ }^{\circ} \mathrm{C}$. Samples were immersed in it and kept at $37{ }^{\circ} \mathrm{C}$ for 7 days, and the SBF solution was refreshed very other day.

\section{In vivo experiments}

All the animal experiments were complied with the arrive guidelines, which has been approved by the animal care and experiment committee of Xi'an Jiaotong University College of Medicine. To reduce the numbers of animals used in the experiments and minimize the influence of individual differences among rabbits, three holes $\left(\Phi 2 \times \mathrm{L} 6 \mathrm{~mm}^{3}\right)$ were drilled through the cortical bone in each tibia of rabbit for placing the $\mathrm{Ti}, \mathrm{MAO}-\mathrm{TiO}_{2}$ and $\mathrm{SnO}_{2}-\mathrm{TiO}_{2}$ implants (Fig. S1, ESI + ). Six New Zealand rabbits with the weight of $2.5^{\sim 3} \mathrm{~kg}$ were used in the work.

Surgical procedures. The rabbits were anaesthetized with pentobarbital sodium $\left(40 \mathrm{mg} \cdot \mathrm{kg}^{-1}\right)$ via injecting into the ear vein. The legs were shaved, depilated, and disinfected with iodine. The rabbit was placed on a sterile drape to provide sterile conditions during surgery. After the tibia was exposed by skin incision, holes were drilled in tibia with tooth plant equipment under a cooling condition by saline water for placing implants. The muscular fascia, subcutaneous tissue, and skin were sutured in sequence. Every rabbit was injected with an antibiotic of gentamicin by a dose of $1 \mathrm{~mL}$ per day for 3 days. The normal dietary intake by rabbit was performed, and a sutured line was removed after implantation for 10 days.

Sample preparation. The rabbits were chosen randomly to be observed at two periods of 4 and 12 weeks after surgery. The chosen rabbits were sacrificed by the injection of air into the ear vein. Immediately, the tibia was detached from the rabbits for further treatment. Meanwhile, the remained organs were treated safely by the staff of the animal experiment center according to the guidelines.

Radiographic evaluation. The X-ray images of implants were taken by an X-ray 3D imaging system (Y. Cheetah, YXLON International $\mathrm{GmbH}$, Germany) to examine the implantation status.

Histological evaluation. The fluorescence labelling stained sections were directly conducted on an OLYMPUS microscope (CXX41, OLYMPUS, Japan) with fluorescence and white light source, which were analyzed for evidence of bone regeneration at different time of 4,8 , and 12 weeks.

For the fluorescence labelling stain, the tetracycline hydrochloride $\left(10 \mathrm{mg} \cdot \mathrm{mL}^{-1}, 30 \mathrm{mg} \cdot \mathrm{kg}^{-1}\right)$ and calcein $\left(10 \mathrm{mg} \cdot \mathrm{mL}^{-}\right.$
$1,5 \mathrm{mg} \cdot \mathrm{kg}^{-1}$ ) were subcutaneously injected into the rabbits at

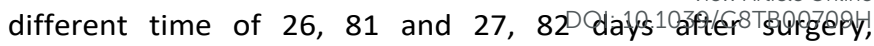
respectively. And the tetracycline hydrochloride $\left(10 \mathrm{mg} \cdot \mathrm{mL}^{-1}\right.$, $\left.30 \mathrm{mg} \cdot \mathrm{kg}^{-1}\right)$ and alizarin red $\left(10 \mathrm{mg} \cdot \mathrm{mL}^{-1}, 30 \mathrm{mg} \cdot \mathrm{kg}^{-1}\right)$ were subcutaneously injected into the rabbits at different time of 54 and 55 days after surgery, respectively.

The following landmarks were used for histomorphometric measurement of the bone tissue around the implant in the interested zone (IZ) (Fig. S2): the ratios of biological tissue and gap in the fluorescence labeling stained region with a distance of $500 \mu \mathrm{m}$ to the cylindrical surface of implants. ImageJ 1.48 software was used for image analyses.

Measurement of push-out force for the implants. The push-out test was carried out using a universal testing machine (Instron1186, Instron Co., USA) with a penetrator in diameter of 1.8 $\mathrm{mm}$. The fracture surfaces of implants were fixed by $2.5 \%$ glutaraldehyde overnight, washed by the PBS and dehydrated in graded ethanol solutions, and then examined by SEM for the failure mode analyses.

Statistical analysis. Three rabbits were used for the histological analyses, while another three rabbits were used for the biomechanical push-out test at 4 weeks after surgery. All the data were expressed as means \pm standard deviations $(n=6)$. The statistical analysis was done by using the IBM SPSS statistical software package. The statistical significance of the difference was measured using a student analysis of variance. The $P$ values $<0.05$ were considered a statistically significant difference.

\section{Results and discussion}

Obviously, the phase formation of MAO coated Ti is dominated by the applied voltage (Fig. 1). Only the typical peaks of $\alpha$-Ti are observed from the XRD pattern of MAO-Non formed at $250 \mathrm{~V}$, while new peaks of anatase at $25.7^{\circ}$ and $38.2^{\circ}$ with weak intensity are obtained on the XRD pattern of MAOAnatase formed at $350 \mathrm{~V}$. As for the XRD pattern of the MAO$\mathrm{TiO}_{2}$ which is formed at $450 \mathrm{~V}$, characteristic peaks of both anatase and rutile are obtained. After hydrothermal treatment, new peaks at $26.1^{\circ}, 33.5^{\circ}$, and $38.3^{\circ}$ are observed in every XRD pattern of MAO coated samples, indicating the formation of $\mathrm{SnO}_{2}$. Interestingly, $\mathrm{Ti}_{8} \mathrm{O}_{15}$ but not $\mathrm{SnO}_{2}$ is formed on the surface of $\mathrm{HT}$-Ti. The reason for this may be attributed to the reaction between $\mathrm{NaOH}$ and substrate. Because $\mathrm{NaOH}$ is easier to react with $\mathrm{Ti}$ than to $\mathrm{TiO}_{2}$, certain reaction consumes a large amount of $\mathrm{NaOH}$, leading to the change of $\mathrm{SnO}_{2} \cdot \mathrm{xH}_{2} \mathrm{O}$ solubility in the bulk solution. Therefore, $\mathrm{SnO}_{2}$ is difficult to form on $\mathrm{Ti}$ surface, because it would be easier for $\mathrm{SnO}_{2}$ to nucleate and grow in the bulk solution under the supersaturation of $\mathrm{SnO}_{2} \cdot \mathrm{xH}_{2} \mathrm{O}$ at lower $\mathrm{pH}$ value. ${ }^{23}$ 

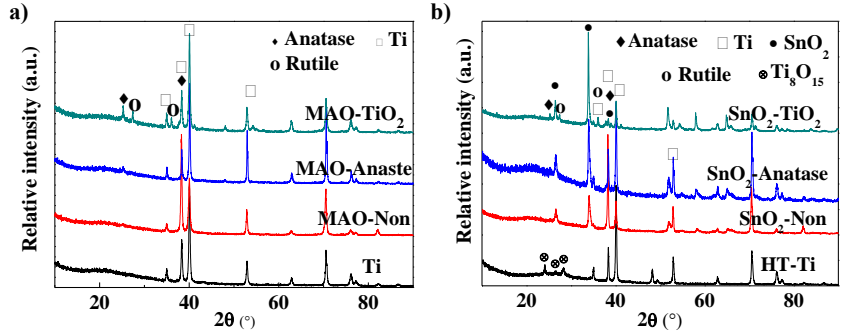

Fig. 1 XRD patterns of Ti and MAO coated Ti samples before and after hydrothermal treatment: a) XRD patterns of samples before hydrothermal treatment, and b) XRD patterns of samples after hydrothermal treatment.
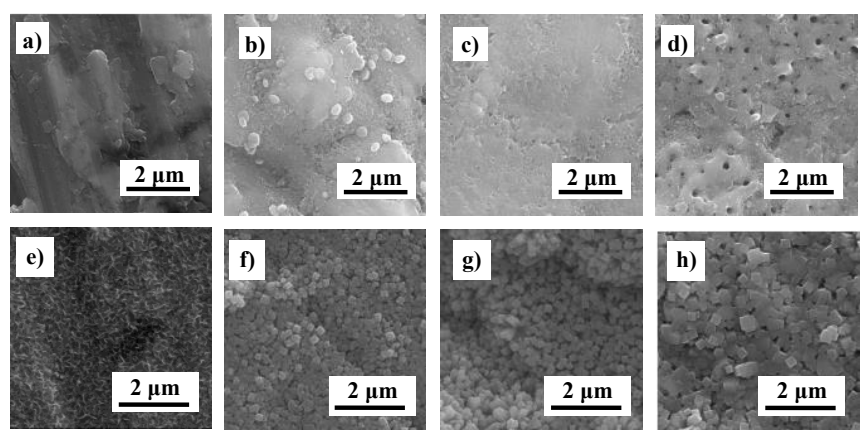

Fig. 2 SEM morphologies of $\mathrm{Ti}$ and MAO coated $\mathrm{Ti}$ samples before and afte hydrothermal treatment: a) Ti, b) MAO-Non, c) MAO-Anatase, d) MAO-TiO $\mathrm{M}_{2}$ e) $\mathrm{HT}-\mathrm{Ti}, \mathrm{f}$ ) $\mathrm{SnO}_{2}$-Non, g) $\mathrm{SnO}_{2}$-Anatase, and h) $\mathrm{SnO}_{2}-\mathrm{TiO}_{2}$.

SEM morphologies of Ti and MAO coated Ti samples before and after hydrothermal treatment are shown in Fig. 2. It is clear that the applied voltage significantly changes the surface morphology of MAO treated $\mathrm{Ti}$ samples. Some particle-like depositions are formed on the surface of MAO-Non, while an oxidized film is formed on the surface of MAO-Anatase according to the EDS results (Fig. S3, ESIt). A typically porous oxidized coating is formed on the surface of $\mathrm{MAO}^{-\mathrm{TiO}}{ }_{2}$. After hydrothermal treatment, rod-like films are formed on the MAO coated Ti samples, while the size of the nano-scale rods is greatly affected by the surfaces formed at different applied voltages. With the increase of the applied voltage, the diameter of as-formed nanorod increases, but the interdistance of the nanorods decreases.

The reasons for the difference in $\mathrm{SnO}_{2}$ generation are mainly attributed to two factors, namely, the surface morphology and the crystal structure matching. Obviously, the rough surface can enhance nuclei due to the heterogeneous nucleation, facilitating the growth of crystal. Regarding the crystal structure matching, $\mathrm{TiO}_{2}$ shows a semi-crystalline match structure with $\mathrm{SnO}_{2}$, which can promote the growth of $\mathrm{SnO}_{2}$ plane (200) along the plane (004) of anatase due to the habit growth relationship. As a result, $\mathrm{SnO}_{2}$ can be generated fast on the surface of MAO coated Ti due to the formation of the oxidized titanium film, attributing to the high crystallinity of $\mathrm{TiO}_{2}$ on $\mathrm{MAO}-\mathrm{TiO}_{2}$ and the porous surface structure of the coating which meet the requirements of the nucleation and growth of $\mathrm{SnO}_{2}$. As a result, $\mathrm{SnO}_{2}$ shows fast growth rate on its surface with large nanorod size in diameter. In terms of the MAO-Non, the oxidized titanium film is amorphous phase according to the XRD and EDS results (Fig. 1 and S3, ESIt).
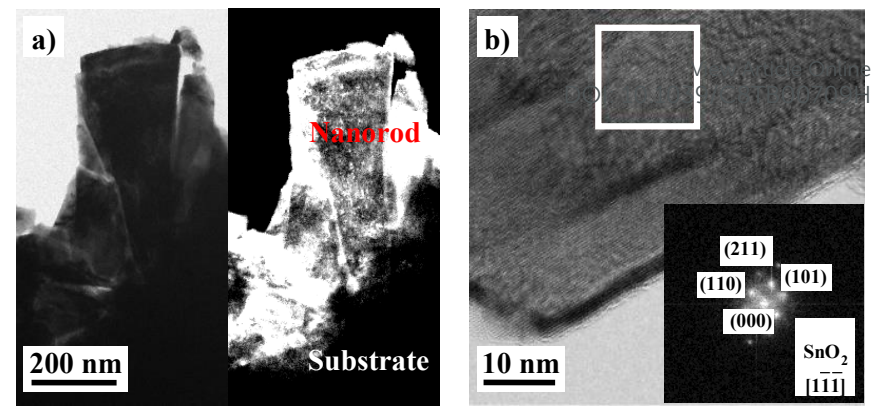

Fig. 3 TEM analysis of the nanorod like crystal formed on $\mathrm{SnO}_{2}-\mathrm{TiO}_{2}$ : a) the bright and dark field TEM morphology, b) HRTEM morphology and SEAD obtained by FFT from the white box area.

Because of the poor crystallinity of oxidized film, it does not facilitate $\mathrm{SnO}_{2}$ growth based on crystal structure matching. The $\mathrm{SnO}_{2}$ formed on MAO-Non surface shows the relatively low amount and small size (Fig. 2 and S4, ESIt).

In order to further confirm the growth of $\mathrm{SnO}_{2}$ nanorod on MAO coating, the powders on the $\mathrm{SnO}_{2}-\mathrm{TiO}_{2}$ surface have been studied by TEM to identify the structure and phase of the coating (Fig. 3). It is clear that the powder collected from the surface consists of two different areas. As for the bright nanorod in the dark field image, it is about $200 \mathrm{~nm}$ in diameter and $400 \mathrm{~nm}$ in length, and mainly composed of $\mathrm{Sn}$ and O. The SAED pattern obtained by FFT is shown in Fig. 3 (b). The spacings of $0.268,0.185$ and $0.337 \mathrm{~nm}$ are aspect to the (101), (211) and (110) planes of $\mathrm{SnO}_{2}$, and the angle of $30.1^{\circ}$ measured from the SAED pattern is well matched with the theoretical angle of $30.0^{\circ}$ between (101) and (211). Regards to the dark substrate area, it is mainly composed of $\mathrm{Ti}$ and $\mathrm{O}$. Thus, we can confirm that the oxidized titanium interlayer can facilitate the growth of $\mathrm{SnO}_{2}$ nanorod on its surface.

Fig. 4 shows the contact angle (CA) of deionized water on the MAO coated Ti plates before and after the hydrothermal treatment. The CAs of the MAO coating covered Ti plate show familiar results, which is regularly identified as the hydrophobic surface. After hydrothermal treatment, the surfaces of $\mathrm{SnO}_{2}-\mathrm{Non}$ and $\mathrm{SnO}_{2}$-Anatase still remain hydrophobic property, while the $\mathrm{CA}$ of $\mathrm{SnO}_{2}-\mathrm{TiO}_{2}$ decreases to $9.8 \pm 1.2^{\circ}$ exhibiting an excellent hydrophilic property.

Meanwhile, it is clear from Table 1 that the zeta potential value of the as-formed MAO samples decreases with the increase of applied voltage. This is attributed to the differences in phase and crystallinity of the as-formed MAO coatings (Fig. 1), because crystallized $\mathrm{TiO}_{2}$ shows a more negative surface potential when compared with the amorphous one. ${ }^{24}$ Interestingly, the surfaces of samples show more negative surface potential after hydrothermal treatment. As for $\mathrm{SnO}_{2}-$ $\mathrm{TiO}_{2}$, its zeta value is $-4.99 \pm 1.23 \mathrm{mV}$.

Table 1 Zeta potential values of the samples without and with $\mathrm{SnO}_{2}$ film

\begin{tabular}{ccc}
\hline Sample & \multicolumn{2}{c}{ Zeta potential value $(\mathrm{mV})$} \\
\cline { 2 - 3 } Code & without SnO2 & with SnO2 \\
\cline { 2 - 3 } MAO-Non & $0.09 \pm 1.12$ & $-0.50 \pm 0.63$ \\
MAO-Anatase & $-0.50 \pm 1.14$ & $-0.93 \pm 0.08$ \\
MAO-TiO2 & $-3.56 \pm 1.10$ & $-4.99 \pm 1.23$ \\
\hline
\end{tabular}



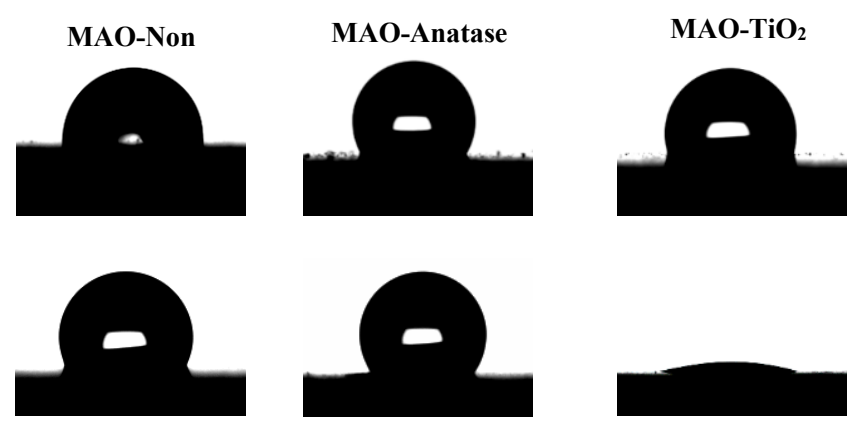

$\mathrm{SnO}_{2}$-Non

$\mathrm{SnO}_{2}$-Anatase

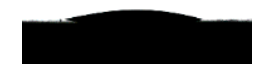

$\mathrm{SnO}_{2}-\mathrm{TiO}_{2}$

Fig. 4 Contact angle of deionized water on MAO coated Ti samples before and after hydrothermal treatment.

Normally, $\mathrm{SnO}_{2}$ is a hydrophilic material and the water $\mathrm{CA}$ on smooth $\mathrm{SnO}_{2}$ film is about $20^{\circ}$, and the wettability of $\mathrm{SnO}_{2}$ can also be strongly affected by surface structure. ${ }^{25}$ Similar to lotus leaf, the nanorod surface of $\mathrm{SnO}_{2}$ exhibits hydrophobicity, because the air pocket prevents the penetration of the water droplet into the grooves and causes the water droplet suspended on the surface of the films. ${ }^{26}$ Herein, though the diameter and inter-distance of the $\mathrm{SnO}_{2}$ nanorod changes, the $\mathrm{SnO}_{2}$ films still show nanorods morphology. According to Cassie and Baxter's model, these surfaces covered with $\mathrm{SnO}_{2}$ nanorods are expected to exhibit hydrophobicity. However, the $\mathrm{SnO}_{2}-\mathrm{TiO}_{2}$ surface shows hydrophilicity in this work (Fig. 4). Interestingly, both the hydrophilicity and the negative zeta potential of the composited coating are closely related to the semi-conductive feature of both $\mathrm{SnO}_{2}$ and $\mathrm{TiO}_{2}$, which can normally show a change in wettability from super hydrophobicity to super hydrophilicity under UV-irradiation due to the formation of hole-electron pairs. ${ }^{27-29}$ For the $\mathrm{SnO}_{2}$ or $\mathrm{TiO}_{2}$ film, some of the holes generated during UV-irradiation can oxidize lattice oxygen to form dissociative oxygen, and oxygen vacancies will form on the surface. ${ }^{26}$ Water molecules are more favoured by the defective sites than oxygen molecules in the air because of the strong adsorption between oxygen vacancy and hydroxyl group, leading to the hydrophilicity of the surface. ${ }^{30}$ Herein, the $\mathrm{SnO}_{2}$ and $\mathrm{TiO}_{2}$ show the type-Il band alignment structure which can form an $n-n$ heterojunction to promote charge separation, leading electrons transfer from $\mathrm{TiO}_{2}$ to $\mathrm{SnO}_{2} .{ }^{17}$ Thus, the $\mathrm{SnO}_{2}-\mathrm{TiO}_{2}$ surface shows more negative zeta potential compared with the MAO coated one because of the enrichment in electrons (Table 1). Meanwhile, the generated oxygen vacancies on the surface are based on the enriched holes, which are formed at the $\mathrm{TiO}_{2}$ layer near the interface of the bi-layered coating benefiting from the charge separation effect of $n-n$ heterojunction. Attributing to the strong adsorption between oxygen vacancy and hydroxyl group, the developed $\mathrm{SnO}_{2}-\mathrm{TiO}_{2}$ surface exhibits excellent hydrophilicity. In addition, the $\mathrm{SnO}_{2}$ amount on the surface film is also another key point for the charge separation based on the $n-n$ heterojunction. Though electron carriers can be effectively separated on the basis of a small amount of $\mathrm{SnO}_{2}$ on $\mathrm{TiO}_{2}$ layer,

it cannot provide enough holes and electrons to affecto the macroscopic properties of the surface. This: poiptiscsipporeed by the results based on short time treated $\mathrm{SnO}_{2}-\mathrm{TiO}_{2}$. With the varied $\mathrm{SnO}_{2}$ amount from 11.8 at.\% to 14.1 at.\%, more electrons would be separated by $n-n$ heterojunction, exhibiting more negative zeta potential vale (between -1.91 $\mathrm{mV}$ and $2.78 \mathrm{mV})$ on the surface than that of $\mathrm{SnO}_{2}$-Non $(-0.50 \mathrm{mV})$. Meanwhile, similar results have been observed in wettability of $\mathrm{SnO}_{2}-\mathrm{TiO}_{2}$, it changes from hydrophobicity to hydrophilicity with the prolongation of the soaking time from $4 \mathrm{~h}$ to $8 \mathrm{~h}$ (Fig.S5, ESI + ). Therefore, an enhancement in hydrophilicity of $\mathrm{SnO}_{2}-\mathrm{TiO}_{2}$ surface is obtained, which is considered as a suitable environment for proteins adsorption and osteoblast attachment. $3,4,31,32$

To confirm this point for the hydrophilic property and negative zeta potential of the $\mathrm{SnO}_{2}-\mathrm{TiO}_{2}$ surface, the MottSchottky plots of the MAO coated Ti samples before and after hydrothermal treatment have been investigated. As shown in Fig. 5(a), the MAO-anatase and $\mathrm{MAO}-\mathrm{TiO}_{2}$ exhibit a positive slope in the MS plots, revealing the formation of n-type semiconductors. Meanwhile, the positive slope increases after the formation of the $\mathrm{SnO}_{2}$ film, suggesting the n-type semiconductor of $\mathrm{SnO}_{2}$. Interestingly, the $\mathrm{SnO}_{2}-\mathrm{TiO}_{2}$ shows a typical n-type semiconductor feature with two different positive slopes around the range of $-0.5 \sim 0.5 \mathrm{~V}$. Electron carrier densities of $\mathrm{SnO}_{2}-\mathrm{TiO}_{2}$ in the two different slope areas are calculated to be $7.78 \times 10^{16} \mathrm{~cm}^{-3}\left(\mathrm{TiO}_{2}\right.$ inner layer) and $4.48 \times$ $10^{18} \mathrm{~cm}^{-3}\left(\mathrm{SnO}_{2}\right.$ skin film), respectively. As for the $\mathrm{MAO}-\mathrm{TiO}_{2}$, it is $4.78 \times 10^{17} \mathrm{~cm}^{-3}\left(\mathrm{TiO}_{2}\right.$ layer), and the electron carrier density of $\mathrm{SnO}_{2}$-Non is calculated to be $3.23 \times 10^{18} \mathrm{~cm}^{-3}\left(\mathrm{SnO}_{2}\right.$ film). Based on the results outlined above, we conclude that an $n-n$ heterojunction was constructed on the $\mathrm{SnO}_{2}-\mathrm{TiO}_{2}$ due to its bilayered structure (Fig. 5(d)), as the electron carriers obviously transfer from inside $\mathrm{TiO}_{2}$ layer to the surface $\mathrm{SnO}_{2}$ film
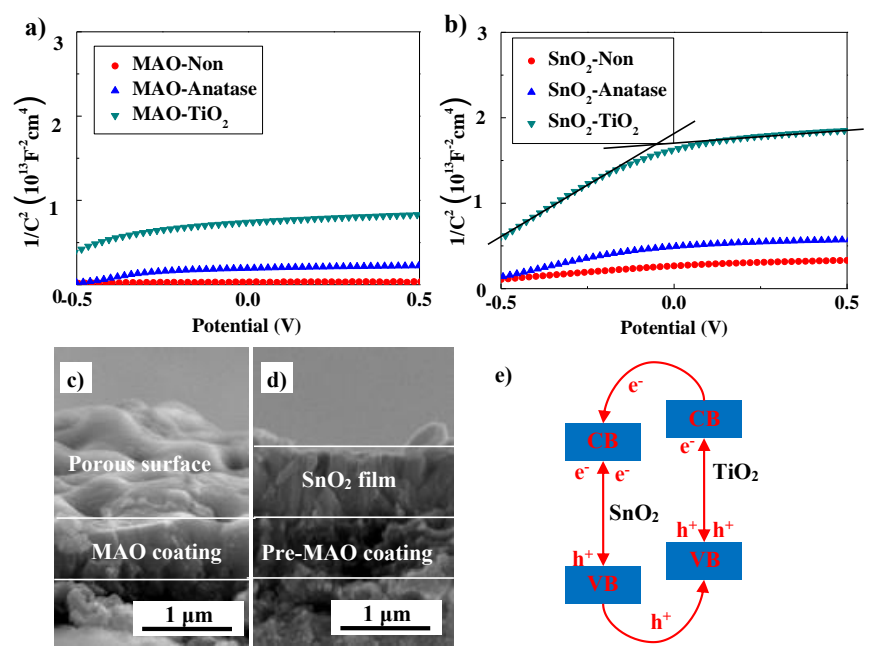

e)

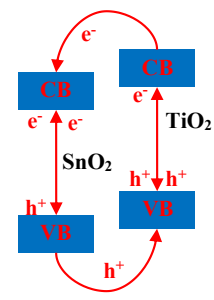

Fig. 5 Mott-Schottky plots and fracture morphologies of the MAO coated Ti before and after hydrothermal treatment: a) Mott-Schottky plots of the MAO coated Ti samples, b) Mott-Schottky plots of the MAO coated Ti samples after hydrothermal treatment, c) and d) fracture morphologies of the $\mathrm{MAO}^{-\mathrm{TiO}_{2}}$ and $\mathrm{SnO}_{2}-\mathrm{TiO}_{2}$, respectively, e) type-II band alignment structure of $\mathrm{SnO}_{2}$ and $\mathrm{TiO}_{2}$. 
confirmed by the change in their density among the $\mathrm{SnO}_{2}-\mathrm{TiO}_{2}$, $\mathrm{MAO}-\mathrm{TiO}_{2}$, and $\mathrm{SnO}_{2}$-Non. Therefore, the negative surface potential and hydrophilicity of $\mathrm{SnO}_{2}-\mathrm{TiO}_{2}$ would be attributed to the formation of the $n-n$ heterojunction.

Herein, it should be noticed that the performance of semiconductor is closely related to crystal structure, since the band gap would be varied due to the change in phase composition and defective state in crystal lattice. ${ }^{33,34}$ In theory, the band gap of anatase is slightly larger than that of rutile, so the charge separation effect of the $n-n$ heterojunction formed by $\mathrm{SnO}_{2}$ and anatase is expected to be slightly different from that of the heterojunction formed by $\mathrm{SnO}_{2}$ and $\mathrm{TiO}_{2}$ (anatase/rutile) based on the band gap. In detail, the conduction band (CB) edges of anatase $\mathrm{TiO}_{2}$ and $\mathrm{SnO}_{2}$ are situated at -0.34 and $+0.07 \mathrm{eV}$ versus normal

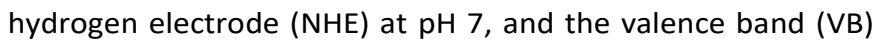
edge of $\mathrm{SnO}_{2}(+3.67 \mathrm{eV})$ is much positive than that of anatase $\mathrm{TiO}_{2}(+2.87 \mathrm{eV}) .{ }^{35}$ This structure belongs to the type II energy band alignment as shown in Fig. 5(e), which can benefit the charge separation. Regarding the rutile $\mathrm{TiO}_{2}$, a consensus place of the $\mathrm{CB}$ for rutile lies $0.2 \mathrm{eV}$ below that of anatase, which should be -0.14 eV. ${ }^{36-38}$ The heterojunction formed by $\mathrm{SnO}_{2}$ and rutile $\mathrm{TiO}_{2}$ also belongs to the type II energy band alignment, but the charge separation effect is expected to be slightly less than that of the heterojunction formed by $\mathrm{SnO}_{2}$ and anatase $\mathrm{TiO}_{2}$ due to the reduction in distance of $\mathrm{CBS}$ between $\mathrm{TiO}_{2}$ and $\mathrm{SnO}_{2}$. As for the mixed phase $\mathrm{TiO}_{2}$, both $\mathrm{CB}$ and VB should lie between those of anatase and rutile, ${ }^{37}$ thus the charge separation effect of the heterojunction formed by $\mathrm{SnO}_{2}$ and $\mathrm{TiO}_{2}$ (anatase/rutile) is expected to be slightly less when compared with that of the heterojunction formed by $\mathrm{SnO}_{2}$ and anatase $\mathrm{TiO}_{2}$. However, the charge separation effect of $\mathrm{SnO}_{2}-\mathrm{TiO}_{2}$ is obviously better than that of the $\mathrm{SnO}_{2}$-anatase. The reason for this should be attributed to the differences in phase and crystallinity of the prepared MAO coatings, which cannot be considered as pure crystal but mixed phase of $\mathrm{TiO}_{2}$. It is clear that the $x$-ray diffraction peak intensity of anatase in $\mathrm{SnO}_{2}-\mathrm{TiO}_{2}$ is 2.23 times stronger than that of $\mathrm{SnO}_{2}$-anatase with the diffraction peak of Ti substrate as a reference (Fig. 1). This indicates that more anatase has been formed in the previous MAO layer of $\mathrm{SnO}_{2}-\mathrm{TiO}_{2}$ than that of $\mathrm{SnO}_{2}$-anatase. Besides, it is also accepted that the MAO coating formed at low applied voltage would be composed of the amorphous phase. ${ }^{39}$ Thus, the previous $\mathrm{MAO}$ layer in $\mathrm{SnO}_{2}$-anatase should be considered as a mixed phase of anatase and amorphous $\mathrm{TiO}_{2}$, but not pure anatase. Furthermore, it has been reported that the pure amorphous $\mathrm{TiO}_{2}$ is inactive for the photocatalytic reaction. ${ }^{34}$ Consistent with this point, the amorphous film of oxidized titanium in MAO-Non cannot show any semiconductor feature according to the Mott-Schottky plot (Fig. 5(a)). Due to the poorer photocatalytic activity of amorphous $\mathrm{TiO}_{2}$ than that of rutile, the charge separation effect of $\mathrm{SnO}_{2}$-anatase would be obviously less when compared with that of $\mathrm{SnO}_{2}-\mathrm{TiO}_{2}$ with relatively high crystallinity. Additionally, Scanlon et al. also reports another possibility of the energy band alignment between anatase and rutile, which indicates that the conduction band edge of anatase lies below $0.2 \mathrm{eV}$ than that of rutile. ${ }^{11} \mathrm{VIn}$ this Gase, even for the pure crystal, the charge separation eqfect $\mathrm{TiO}_{2}$ would obviously larger than that of $\mathrm{SnO}_{2}$-anatase because of the increase in the distance of CVs and CBs. Based on above discussion, the phase composition and crystallinity of the MAO coating would significantly affect the charge separation effect of the $n-n$ heterojunction in this work.

The XPS spectra detected from the surface of the $\mathrm{SnO}_{2}-\mathrm{TiO}_{2}$ before and after Ar etching are shown in Fig. 6, from which Ti, Sn, $O$ and $C$ have been detected. Similar Sn $2 p$ and $T i 2 p$ spectra have been obtained before and after Ar etching, the states of $\mathrm{Sn}^{4+}$ and $\mathrm{Ti}^{4+}$ indicate the formation of the $\mathrm{SnO}_{2}$ and $\mathrm{TiO}_{2}$. However, the $\mathrm{C} 1 \mathrm{~s}$ and $\mathrm{O} 1 \mathrm{~s}$ spectra show obviously different in spectra after the Ar etching. The divided gaussian peaks of $O 1 \mathrm{~s}$ and $C 1 \mathrm{~s}$ spectra before Ar etching indicate the formation of hydroxides, $\mathrm{C}-\mathrm{O}$, and carbonates on its surface, ${ }^{40-}$ 42 while these peaks are disappeared from the spectra after $\mathrm{Ar}$ etching. This phenome supports the charge separation effect of the $n-n$ heterojunction, because the absorbed $\mathrm{H}_{2} \mathrm{O}, \mathrm{C}$ and $\mathrm{CO}_{2}$ are easy to react with oxygen vacancies obtained by charge separation to form the hydroxides, C-O, and carbonates.

Normally, the $\mathrm{SnO}_{2}$ film is considered as biocompatible materials used in the field of bio-sensor and antibacterial aspects, while no result of bioactivity has been reported even after SBF immersion. 21,22 However, recent investigations indicate that bioactivity not only caused by the chemical composition of the surface, but also the physical properties of the film, especially the electric properties. ${ }^{1-5}$ Thus the apatiteinducing ability of the as-formed samples was investigated via $1.5 \times$ SBF immersions for 7 days (Fig. 7) in this work. It is clear that a network film is deposited on the $\mathrm{SnO}_{2}-\mathrm{TiO}_{2}$ surface (Fig. $7(\mathrm{f})$ ). Combined with the EDS and FT-IR results (Fig. 7(g) and (h)), it is clear that this covered film on $\mathrm{SnO}_{2}-\mathrm{TiO}_{2}$ is carbonated apatite. However, the other samples retain their surface
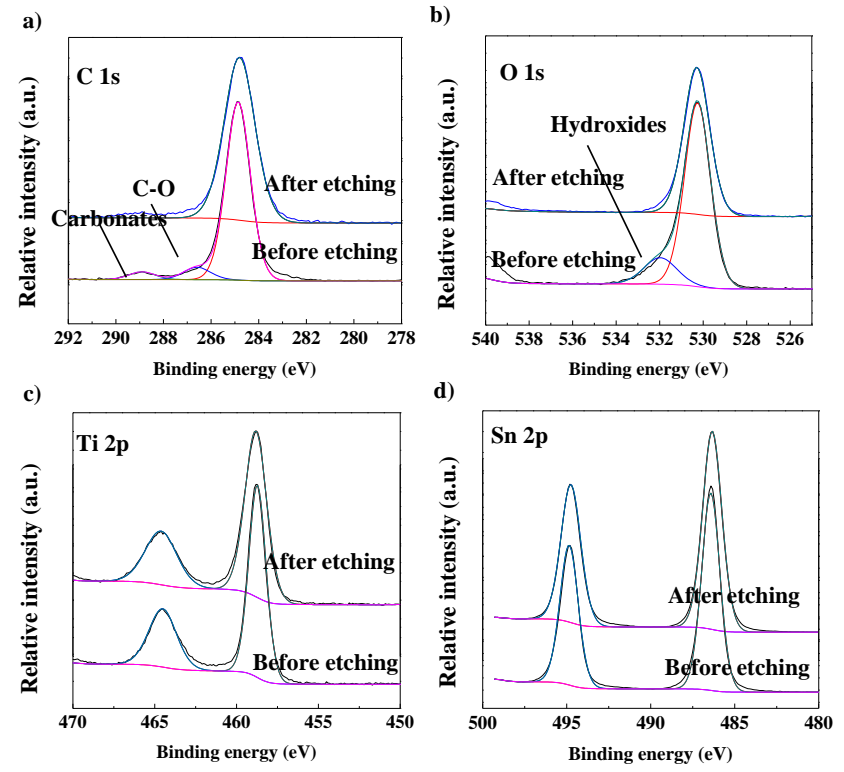

Fig. 6 XPS spectra of the $\mathrm{SnO}_{2}-\mathrm{TiO}_{2}:$ a) C 1s, b) O 1s, c) Ti 2p, and d) Sn 2p. 
structure without any deposition indicating the relatively poor bioactivity of the surfaces compared with that of $\mathrm{SnO}_{2}-\mathrm{TiO}_{2}$. Though some previous works have reported that the $\mathrm{TiO}_{2-}$ based MAO coatings can induce apatite after SBF immersion, but it requires long immersion time for about one month. ${ }^{43}$ Herein, the $\mathrm{MAO}^{-\mathrm{TiO}_{2}}$ was immersed in the $1.5 \times \mathrm{SBF}$ for only 7 days, thus no apatite was observed on its surface. The bioactivity of $\mathrm{SnO}_{2}-\mathrm{TiO}_{2}$ is in agreement with a recent report that metal oxides nanoparticles with a negative charge exhibit high calcium-adsorption capacity. ${ }^{44}$ Consistent with their result, the $\mathrm{SnO}_{2}$ film with more negative zeta potential could trigger carbonated apatite nucleation, resulting as good apatite-inducing ability of $\mathrm{SnO}_{2}-\mathrm{TiO}_{2}$ when compared with the others (Fig. 7).

As the $\mathrm{SnO}_{2}-\mathrm{TiO}_{2}$ surface shows good apatite-inducing ability and hydrophilicity, the animal experiment is used to evaluate its in vivo performance with the control of $\mathrm{Ti}$ and MAO-TiO 2 implants. Fig. 8(a) shows the typical sagittal and coronal radiographs of the $\mathrm{Ti}, \mathrm{MAO}-\mathrm{TiO}_{2}$ and $\mathrm{SnO}_{2}-\mathrm{TiO}_{2}$ implant after healing for 4 weeks. Obviously, the implants do not cause any adverse effects according to the radiographs. Meanwhile, a capsule is formed on tibia surface around the implantation area of $\mathrm{SnO}_{2}-\mathrm{TiO}_{2}$ due to the formation of new bone. A thicker bone capsule is observed at the area closer to the implant, showing a radiation-like trend. Besides, the cortical bone
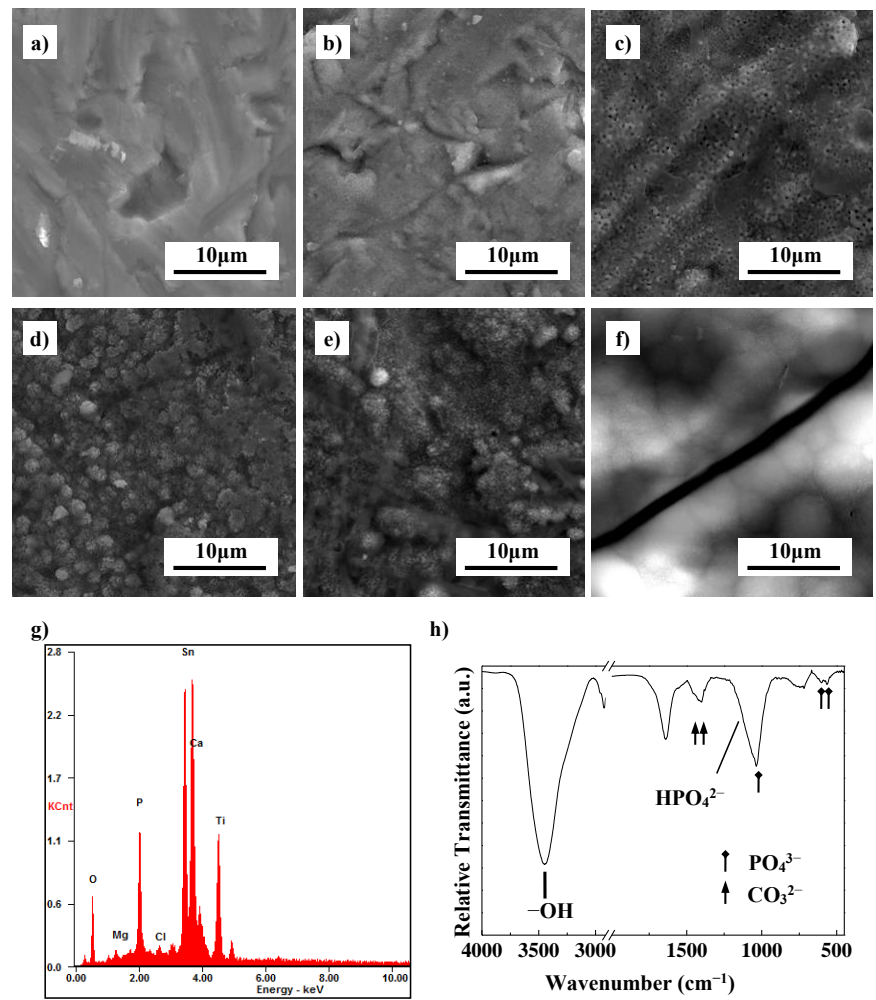

h)

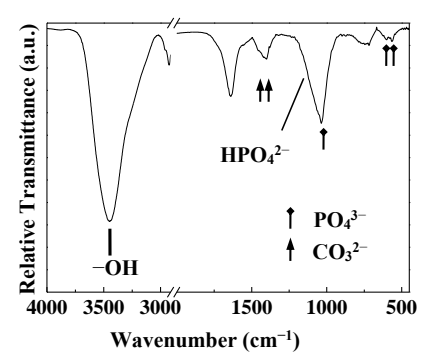

Fig. 7 The apatite-inducing ability of the MAO coated Ti before and after hydrothermal treatment: SEM morphology of a) MAO-Non, b) MAO-Anatase, c) $\mathrm{MAO}-\mathrm{TiO}_{2}$, d) $\mathrm{SnO}_{2}$ Non, e) $\mathrm{SnO}_{2}$-Anatase, and f) $\mathrm{SnO}_{2}-\mathrm{TiO}_{2}$ after $1.5 \times \mathrm{SBF}$ immersion for 7 days, g) EDS spectrum of the surface of $\mathrm{SnO}_{2}-\mathrm{TiO}_{2}$ after $1.5 \times \mathrm{SBF}$ immersion for 7 days, and h) FT-IR spectrum of the deposition on the surface of $\mathrm{SnO}_{2}-\mathrm{TiO}_{2}$ after $1.5 \times \mathrm{SBF}$ immersion for 7 days. shows a tendency to grow along the surface of the $S_{\text {An }} \mathrm{S}_{2}-\mathrm{J}_{\mathrm{i}} \mathrm{O}_{2}$ implant in the area between bone and maprol W' 1 ea not observed on $\mathrm{MAO}-\mathrm{TiO}_{2}$ and $\mathrm{Ti}$ implants. These phenomena indicate that the bi-layered $\mathrm{SnO}_{2}-\mathrm{TiO}_{2}$ surface can accelerate new bone generation. The reason for this can be explained from two aspects i.e. the formation of apatite and growth of collagen fibers, which are considered as two key attributes for bioactive implant based on the mechanism of osseointegration with surrounding bone tissue. ${ }^{45}$ Firstly, the negative charge enriched surface can promote apatite-formation. ${ }^{44}$ Consistent with this suggestion, the oxidized titanium surface with densely packed $\mathrm{SnO}_{2}$ nanorods $\left(\mathrm{SnO}_{2}-\mathrm{TiO}_{2}\right.$ surface) which shows more negative surface charge based on heterojunction exhibits better apatite-inducing ability than the ones without heterojunction feature (Fig. 7). Meanwhile, due to the electric properties of the bone tissue, the activity of protein and cell can be activated by the potential difference between the surface and the surrounding tissues. ${ }^{46}$ Therefore, $\mathrm{SnO}_{2}-\mathrm{TiO}_{2}$ surface provides a suitable environment for bone growth, as it perfectly meets the requirements for the osseointegration of implant.

We believe here the internal electric stimulation played a predominant role rather than the nano-topography of the $\mathrm{SnO}_{2}-\mathrm{TiO}_{2}$ surface. As for the nano-topographic patterns created surfaces, integrin lateral clustering as a consequence of ligand density and spacing on materials strongly affects focal adhesion assembly and dynamics of cells. ${ }^{47-49} \mathrm{~A}$ recent work suggests that the $\mathrm{TiO}_{2}$ nanorods with a height of $15 \mathrm{~nm}$ and a spacing of $50 \mathrm{~nm}$ on Ti surface can enhance osteogenic expression. ${ }^{50} \mathrm{Ning}$ indicates that the nanorod surface of $\mathrm{TiO}_{2}$ with a height of $23 \mathrm{~nm}$ and an optimal spacing of $55 \mathrm{~nm}$ on $\mathrm{Ti}$ implant could improve bone-bonding strength by $200 \%$ compared to that of controlled Ti implant after implantation
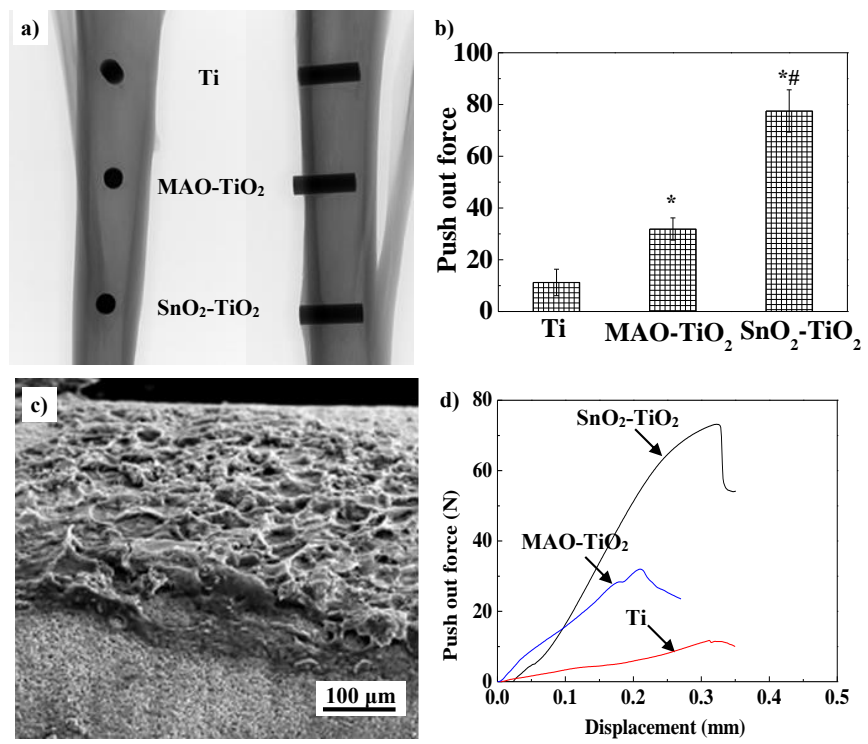

Fig. $8 \mathrm{CT}$ image and push out forces of the Ti, MAO- $-\mathrm{TiO}_{2}$ and $\mathrm{SnO}_{2}-\mathrm{TiO}_{2}$ implants after healing time of 4 weeks: a) CT image of implants, b) push out forces of implants, c) surface morphology of the pushed out $\mathrm{SnO}_{2}-\mathrm{TiO}_{2}$ implant, and d) representative displacement curves of the implants. ${ }^{*} p<0.05$ compared to the Ti implant, $\# p<0.05$ compared to the $\mathrm{MAO}-\mathrm{TiO}_{2}$. 
for 12 weeks. ${ }^{51}$ However, the as-formed $\mathrm{SnO}_{2}$ nanorods in this work are densely packed with a height of near $300 \mathrm{~nm}$ and a narrow spacing of $20 \mathrm{~nm}$ (Fig. 2 and 5(d)), on which cell membranes would be unable to reach surface recesses at the nano intergaps, leading to poor focal adhesion assembly compared with above studies. ${ }^{47}$ Furthermore, the surface roughness of the $\mathrm{SnO}_{2}-\mathrm{TiO}_{2}\left(\mathrm{R}_{\mathrm{a}}=0.080 \pm 0.009 \mu \mathrm{m}\right.$ and $\mathrm{R}_{z}=$ $0.348 \pm 0.052 \mu \mathrm{m})$ and $\mathrm{MAO}-\mathrm{TiO}_{2}\left(R_{a}=0.079 \pm 0.007 \mu \mathrm{m}\right.$ and $R_{z}$ $=0.361 \pm 0.042 \mu \mathrm{m})$ shows similar value without any significant difference. Thus, the nanotopography of the developed $\mathrm{SnO}_{2}$ nanorod surface would play but only a limited role in osteogenic differentiation and bone formation, which would be like that of $\mathrm{MAO}-\mathrm{TiO}_{2}$ due to the similar surface roughness and morphology (Fig. 2). Instead, both apatite and collagen fibers are prone to form on the electrically bioactive surface of the $\mathrm{SnO}_{2}-\mathrm{TiO}_{2}$ implant (Fig. 8(a) and (c)), which may be responsible for significantly enhanced bonding strength between the implant and surrounding bone tissue. As a result, the push-out force of the implant is $77.5 \pm 8.2 \mathrm{~N}$ (Fig. 8 (b)), which is nearly 7 times higher than that of pure Ti implant and twice as that of $\mathrm{MAO}^{-\mathrm{TiO}_{2}}$ surface. It should be pointed out that the osteointegration around the implantation area at the early healing stage is still a significant challenge, though many different approaches have been investigated to improve the bioactivity of $\mathrm{Ti}$ implant. ${ }^{52-56}$ Among these strategies, drugladen and HA coating on implant surface are two most accepted methods to render $\mathrm{Ti}$ with bioactivity due to the excellent in vivo performance. ${ }^{53,54}$ When compared with the literature values for the push out testing results (Table S2, $\mathrm{ESI}+$ ), it reveals that the $\mathrm{SnO}_{2}-\mathrm{TiO}_{2}$ shows similar improvement in bonding strength when compared with the drug-laden or $\mathrm{HA}$ coated $\mathrm{Ti}$ implants at the early stage of healing, but much better performance compared to the no $\mathrm{HA}$ or extracellular matrix (ECM) derived coatings. Thus, the $\mathrm{SnO}_{2}-\mathrm{TiO}_{2}$ surface with the bi-layered structure on $\mathrm{Ti}$ obviously enhances the osseointegration of the implants at the early healing stage of 4 weeks.

In order to ensure the application in long-term load bearing implant, the histological images of the implants after healing of 12 weeks have been also investigated in this work. As observed from the Fig. 9, the green fluorescence lines labeled by brown arrows are pointed to the osteoblast formed at 26 days ( 4 weeks), the yellow fluorescence lines labeled by blue arrows are pointed to the osteoblast stained at 54 days (8 weeks), while the green fluorescence lines labeled by red arrows are corresponded to the osteoblast formed at 82 days (12 weeks). Therefore, we can distinguish the green fluorescence lines formed at different time easily with the help of the yellow one. After healing of 4 weeks, direct boneimplant contact on the surface of the $\mathrm{MAO}-\mathrm{TiO}_{2}$ and $\mathrm{Ti}$ implant is rarely seen, the interface is separated by soft tissue or gaps with wave-like fluorescence lines. Though some gaps have been observed between the $\mathrm{SnO}_{2}-\mathrm{TiO}_{2}$ surface and the surrounding bone tissue, near half of the interface in cortical region exhibits direct bone-implant contact. This is in consistent with the mechanical test results, $\mathrm{SnO}_{2}-\mathrm{TiO}_{2}$ shows good push out force with bone tissue at early healing stage
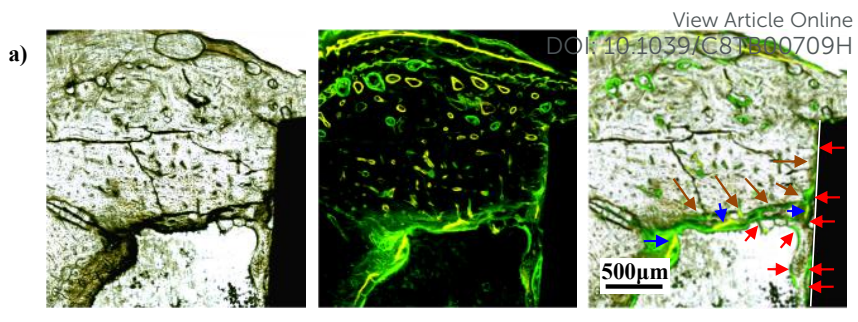

b)
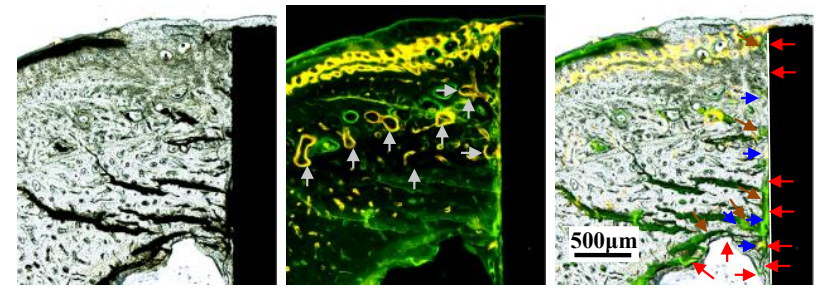

c)
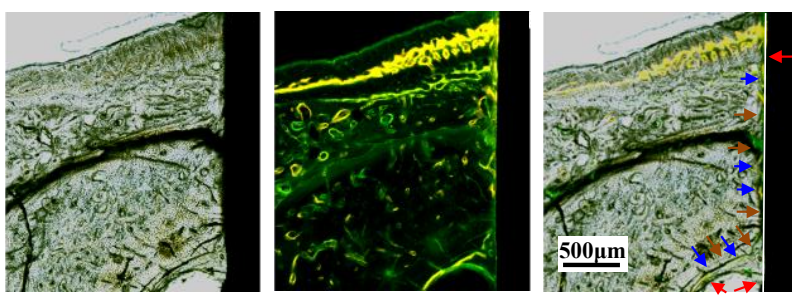

Fig. 9 Histological images, fluorescence labeled images, and the histological images with treble fluorescence labeling at different healing time of 4,8 and 12 weeks: a) Ti implant, b) MAO-TiO2, c) SnO2-TiO2. (Brown arrow) green fluorescence line labeled at 4 weeks; (blue arrow) yellow fluorescence line labeled at 8 weeks; (red arrow) green fluorescence line labeled at 12 weeks; (white dashed line) the ideal interface between implant and bone tissue; (grary arrow) the cavities formed on bone tissue around MAO-TiO2 after healing time of 4 weeks.

(Fig. 8), because most of its surface has been covered by bone tissue. After the surgery for 8 weeks, both the $\mathrm{SnO}_{2}-\mathrm{TiO}_{2}$ and the $\mathrm{MAO}-\mathrm{TiO}_{2}$ are well covered by bone tissue (synostosis). However, the surrounding bone near $\mathrm{MAO}-\mathrm{TiO}_{2}$ surface shows loose structure due to the formation of cavities in the mineral bone which are labeled by gray arrows in Fig. 9(b). After healing of 12 weeks, the $\mathrm{SnO}_{2}-\mathrm{TiO}_{2}$ exhibits excellent osteointegration as it is hard to distinguish the newly formed green fluorescence lines at the interface area, while the

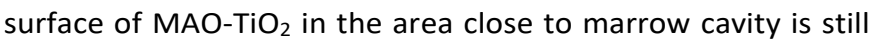
separated by soft tissue or gaps. Regarding to Ti implant, the surface is obviously separated from bone by gaps or soft tissue. This point is strongly supported by the area ratio of gaps in the interested zone (IZ) which is calculated by histological morphometry (Table 2 and Fig. S2, ESIt). Obviously, the bone tissue around $\mathrm{SnO}_{2}-\mathrm{TiO}_{2}$ shows the densest structure with gap ratio of only $0.44 \%$ after healing of 12 weeks, indicating excellent bone regeneration ability. Therefore, the bi-layered $\mathrm{SnO}_{2}-\mathrm{TiO}_{2}$ coating on $\mathrm{Ti}$ substrate shows good bioactivity, which makes it a suitable material for bone tissue replacement and repair.

Table 2 The histomorphometry analysis of biological tissue and gap in the interested zoon. ( $\mathrm{p}<0.05$ compared to the Ti implant, \#p $<0.05$ compared to the MAO-TiO2.)

\begin{tabular}{ccc}
\hline Sample code & Gap ratio (\%) & Biological ratio (\%) \\
\hline Ti implant & $6.27 \pm 1.46$ & $93.73 \pm 1.46$ \\
MAO-TiO2 & $3.17 \pm 0.22^{*}$ & $96.83 \pm 0.22 *$ \\
SnO2-TiO2 & $0.44 \pm 0.07^{*} \#$ & $99.56 \pm 0.07 * \#$ \\
\hline
\end{tabular}




\section{Conclusions}

A bi-layered $\mathrm{SnO}_{2}-\mathrm{TiO}_{2}$ coating has been developed on $\mathrm{Ti}$ surface via a hybrid technology of microarc oxidation and subsequent hydrothermal treatment. The obtained microporous and crystallized $\mathrm{TiO}_{2}$ coating on $\mathrm{Ti}$ substrate is favorable for the growth of the $\mathrm{SnO}_{2}$ nanorods on the $\mathrm{TiO}_{2}$ coating, and the crystallinity of $\mathrm{TiO}_{2}$ is a dominant factor in facilitating the formation of $\mathrm{SnO}_{2}-\mathrm{TiO}_{2}$ heterojunction. Owing to the formation of $n-n$ heterojunction, the $\mathrm{SnO}_{2}-\mathrm{TiO}_{2}$ exhibits negative surface potential, superhydrophilicity, and good apatite-inducing ability. Benefiting from its electrically stimulated bioactivity and nanotopographic surface structure, the developed $\mathrm{Ti}$ implant with bi-layered $\mathrm{SnO}_{2}-\mathrm{TiO}_{2}$ coating shows significant improvement in the bonding strength with surrounding bone tissue, which makes it a suitable material for bone tissue replacement and repair.

\section{Conflicts of interest}

There are no conflicts to declare.

\section{Acknowledgements}

This work was financially supported by the State Key Program of National Natural Science of China (Grant No. 51631007), National Natural Science Foundation of China (Grant No. 51602251), China Postdoctoral Science Foundation (Grant No. 2016M590941 and 2017T100745), and Fundamental Research Funds for the Central Universities (Grant No. xjj2017052). R. Zhou is grateful to the China Scholarship Council (Grant No. 201706285046) for supporting his visiting research at the University of Bristol.

\section{Notes and references}

1 A.H. Rajabi, M. Jaffe and T.L. Arinzeh, Acta Biomater., 2015, 24, 12-23.

2 A. Campetelli, D. Bonazzi and N. Minc, Cytoskeleton, 2012, 69, 601-612.

3 J. Liao, Y. Zhu, Z. Zhou, J. Chen, G. Tan, C. Ning and C. Mao, Angew. Chem. Int. Edit., 2014, 53, 13068-13072.

4 R. Hess, A. Jaeschke, H. Neubert, V. Hintze, S. Moeller, M. Schnabelrauch, H.P. Wiesmann, D.A. Hart and D. Scharnweber, Biomaterials, 2012, 33, 8975-8985.

5 C. Ning, L. Zhou and G. Tan, Mater. Today, 2015, 19, 2-3.

6 M. Geetha, A.K. Singh, R. Asokamani and A.K. Gogia, Prog. Mater. Sci., 2009, 54, 397-425.

7 G. Pan, S. Sun, W. Zhang, R. Zhao, W. Cui, F. He, L. Huang, S.H. Lee, K.J. Shea, Q. Shi and H. Yang, J. Am. Chem. Soc., 2016, 138, 15078-15086.

8 J. Chen, H.B. Yang, H.B. Tao, L. Zhang, J. Miao, H.Y. Wang, J. Chen, H. Zhang and B. Liu, Adv. Funct. Mater., 2016, 26, 456465.

9 C. Ning, P. Yu, Y. Zhu, M. Yao, X. Zhu, X. Wang, Z. Lin, W. Li, S. Wang, G. Tan, Y. Zhang, Y. Wang and C. Mao, NPG Asia Mater., 2016, 8, e243.
10 V. Pfeifer, P. Erhart, S. Li, K. Rachut, J. Morasch, J. Brötz, P.

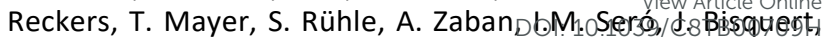
W. Jaegermann and A. Klein, J. Phys. Chem. Lett., 2013, 4, 4182-4187.

11 D.O. Scanlon, C.W. Dunnill, J. Buckeridge, S.A. Shevlin, A.J. Logsdail, S.M. Woodley, C.R.A. Catlow, M.J. Powell, R.G. Palgrave, I.P. Parkin, G.W. Watson, T.W. Keal, P. Sherwood, A. Walsh and A.A. Sokol, Nat. Mater., 2013, 12, 798-801.

12 Y.P. Yuan, L.W. Ruan, J. Barber, S.C.J. Loo and C. Xue, Energy Environ. Sci., 2014, 7, 3934-3951.

13 J. Shang, W. Yao, Y. Zhu and N. Wu, Appl. Catal. A-Gen., 2004, 257, 25-32.

14 Y. Li, Y. Yu, Y. Huang, R.A. Goddard, Y. Li and L. Cao, ACS Catal., 2015, 5, 448-455.

15 C. Mrabet, N. Mahdhi, A. Boukhachem, M. Amlouk and T. Manoubi, J. Alloy. Compd., 2016, 688, 122-132.

16 A.A. Marino and R.O. Becker, Nature, 1970, 228, 473-474.

17 Z. Liu, D.D. Sun, P. Guo and J.O. Leckie, Nano Lett., 2007, 7, 1081-1085.

18 J.A. Curran and T.W. Clyne, Acta Mater., 2006, 7, 1985-1993.

19 R. Zhou, D. Wei, J. Cao, W. Feng, S. Cheng, Q. Du, B. Li, Y. Wang, D. Jia and Y. Zhou, ACS Appl. Mater. Inter., 2015, 7, 8932-8941.

20 H. Wang and A L. Rogach, Chem. Mater., 2014, 26, 123-133.

21 M. Patel, J. Singh, M. Singh, V. Agrawal, S.G. Ansari and B. Malhotra, J. Nanosci. Nanotechno., 2013, 13, 1671-1678.

22 H.K. Varma, K. Sreenivasan, Y. Yokogawa and A. Hosumi, Biomaterials, 2003, 24, 297-303.

23 K. Sato, Y. Yokoyama, J.C. Valmalette, K. Kuruma, H. Abe and T. Takarada, Cryst. Growth Des., 2013, 13, 1685-1693.

24 J. He, Q.Z. Cai, Q. Luo, D.Q. Zhang, T.T. Tang and Y.F. Jiang, Korean J. Chem. Eng., 2010, 27, 435-438.

25 M. Miyauchi, A. Nakajima, T. Watanabe and K. Hashimoto, Chem. Mater., 2002, 14, 2812-2816.

26 W.Q. Zhu, X.J. Feng, L. Feng and L. Jiang, Chem. Commun., 2006, 26, 2753-2755.

27 Y. Lai, J. Huang, Z. Cui, M. Ge, K. Zhang, Z. Chen and L. Chi, Small, 2016, 12, 2203-2224.

28 K. Liu, M. Cao, A. Fujishima and L. Jiang, Chem. Rev., 2014, 114, 10044-10094.

29 W. Zhu, X. Feng, L. Feng and L. Jiang, Chem. Commun., 2006, 26, 2753-2755.

30 R. Sun, A. Nakajima, A. Fujishima, T. Watanabe and K. Hashimoto, J. Phys. Chem. B, 2001, 105, 1984-1990.

31 A. Ranella, M. Barberoglou, S. Bakogianni, C. Fotakis and E. Stratakis, Acta Biomater., 2010, 6, 2711-2720.

32 L.C. Xu and C.A. Siedlecki, Biomaterials, 2007, 28, 32733283.

33 K. Kulbir and C.V. Singh, Energy Procedia, 2012, 29, 291-299.

34 J. Huang, Y. Liu, L. Lu and L. Li, Res. Chem. Intermediat., 2012, 38, 487-498.

35 M.H. Zhou, J.G. Yu, S.W. Liu, P.C. Zhai and L. Jiang, J. Hazard. Mater., 2008, 154, 1141-1148.

36 J. Yu, J.C. Yu, W. Ho and Z. Jiang, New J. Chem., 2002, 26, 607-613.

37 Y. Mi and Y.X. Weng, Sci. Rep., 2015, 5, 11482.

38 M.E. Arroyo-de Dompablo, A. Morales-Garcia and M. Taravillo, J. Chem. Phys., 2011, 135, 054503.

39 R. Zhou, D. Wei, H. Ke, J. Cao, B. Li, S. Cheng, W. Feng, Y. Wang, D. Jia and Y. Zhou, CrystEngComm, 2015, 17, 27052717.

40 T.K. Sham and M.S. Lazarus, Chem. Phys. Lett., 1979, 68, 426432.

41 F.M.F. de Groot, M. Grioni and J.C. Fuggle, Phys. Rev. B, 1989, 40, 5715-5723.

42 A.V. Shchukarey and D.V. Korolkoy, Cent. Eur. J. Chem., 2004, 2, 347-362.

43 D.Q. Wei and Y. Zhou, Ceram. Int., 2009, 35, 2343-2350. 
44 M. Horie and K. Fujita, Advances in Molecular Toxicology, 2011, 5, 145-178.

45 F.X. Maquart, G. Bellon, B. Chaqour, J. Wegrowski, L.M. Patt, R.E. Trachy, J.C. Monboisse, F. Chastang, P. Birembaut, P. Gillery and J.P. Borel, J. Clin. Invest., 1993, 92, 2368-2376.

46 C. Halperin, S. Mutchnik, A. Agronin, M. Molotskii, P. Urenski, M. Salai and G. Rosenman, Nano Lett., 2004, 4, 1253-1256.

47 M. Ventre, F. Causa and P.A. Netti, J. R. Soc. Interface, 2012, 9, 2017-2032.

48 M.J. Dalby, N. Gadegaard, R. Tare, A. Andar, M.O. Riehle, P. Herzyk, C.D.W. Wilkinson and R.O.C. Oreffo, Nat. Mater., 2007, 6, 997-1003.

49 R.A. Gittens, T. McLachlan, R. Olivares-Navarrete, Y. Cai, S. Berner, R. Tannenbaum, Z. Schwartz, K.H. Sandhage and B.D. Boyan, Biomaterials, 2011, 32, 3395-3403.

50 T. Sjöström, L.E. mcNamara, R.M.D. Meek, M.J. Dalby and B. Su, Adv. Healthc. Mater., 2013, 2, 1285-1293.

51 C. Ning, S. Wang, Y. Zhu, M. Zhong, X. Lin, Y. Zhang, G. Tan, M. Li, Z. Yin, P. Yu, X. Wang, Y. Li, T. He, W. Chen, Y. Wang and C. Mao, Sci. Rep., 2016, 6, 19047.

52 Y. Li, S. Zou, D. Wang, G. Feng, C. Bao and J. Hu, Biomaterials, 2010, 31, 3266-3273.

53 M. Nepal, L. Li, T.S. Bae, B. Kim and Y. Soh, Biomol. Ther., 2014, 22, 563-569.

54 J. Yan, J.F. Sun, P.K. Chu, Y. Han and Y.M. Zhang, J. Biomed. Mater. Res. A, 2013, 101, 2465-2480.

55 K. Takahashi, N. Shiraishi, R. Ishiko-Uzuka, T. Anada, O. Suzuki, H. Masumoto and K. Sasaki, Int. J. Mol. Sci., 2015, 16, 5779-5788.

56 C. Castllani, R.A. Lindtner, P. Hausbrandt, E. Tschegg, S.E. Stanzl-Tschegg, G. Zanoni, S. Beck and A.M. Weinberg, Acta Biomater., 2011, 7, 432-440. 


\section{Table of Content Entry}

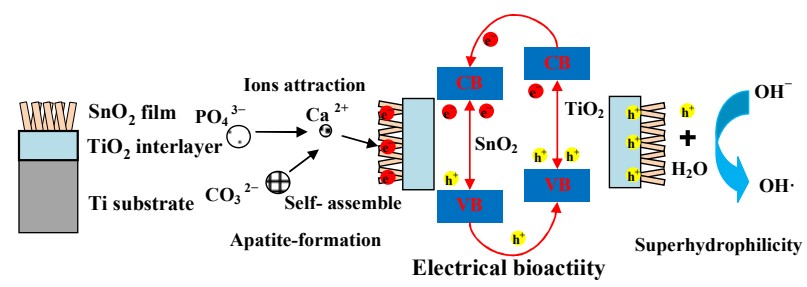

$\mathrm{SnO}_{2}-\mathrm{TiO}_{2}$ surface with the bi-layered structure on $\mathrm{Ti}$ provides internal electric stimulation to promote osteointegration of implant. 